\title{
STUDY ON THE EFFECT OF POLYSACCHARIDES FROM SOLANUM NIGRUM LINNE ON CELLULAR IMMUNE FUNCTION IN TUMOUR-BEARING MICE
}

\author{
Hai Chen and Xiaodong $\mathbf{Q i}^{*}$ \\ Department of Galactophore, The Military General Hospital of Beijing PLA, Beijing, China \\ *E-mail: chenhai10@126.com
}

\begin{abstract}
We investigated the anti-tumour effect of polysaccharides from Solanum nigrum Linne, and its relationship with the immune function of tumour-bearing organisms. MTT assay was used to observe the effect of different doses of polysaccharides from Solanum nigrum Linne on proliferation of lymphocytes in tumour-bearing mice. ELISA assay was also used to detect the levels of IL-2 in mice, and a laser scanning confocal microscope was used to detect the effect of polysaccharides from Solanum nigrum Linne on intralymphocytic free calcium ion concentration in tumour-bearing mice. Different doses of polysaccharides from Solanum nigrum Linne significantly inhibited the growth of mouse H22 solid tumours, improved the survival time of tumour-bearing mice, increased the proliferation of lymphocytes, elevated the levels of IL-2, and increased the concentration of calcium ions in the lymphocytes. Polysaccharides from Solanum nigrum Linne have certain anti-tumour effect, which is related with the cellular immune function that regulates the body.
\end{abstract}

Keywords: Solanum nigrum polysaccharides; tumour-bearing mice; cellular immunity

\section{Introduction}

Chinese herbal medicine, Long Kui, is the whole plant of Solanum nigrum Linne, which is in the genus Solanum, family of Solanaceae. It is widely distributed worldwide. The whole plant of Solanum nigrum Linne can be used as medicine. It is cold in nature, bitter and slightly sweet in taste, slightly toxic, and has the effects of clearing heat, detoxification, invigorating blood circulation, inducing diuresis, and dispersing swelling. Solanum nigrum Linne contains polysaccharides, minerals, vitamins, pigments, and amino acids (Liu et al, 2003; Mi et al, 2002). Solanum nigrum Linne fruit also contains esters, sterols, carboxyl compounds, and saponins (Eldridge, 1983). As an ancient medicine, Solanum nigrum Linne has been playing an important role in the treatment of cancer in China since ancient times. It is reported in the literatures that Solanum nigrum Linne can inhibit tumour cell growth and promote apoptosis of tumour cells, and has immunomodulatory and cytotoxic effects (Son et al, 2003; Yen et al, 2001). Its pharmacological importance also include anti-inflammatory, anti-shock (Jiang, 1977), anti-bacterial, anti-viral (Li et al, 1998), antipyretic, analgesic, cardiovascular protective (Compilation, 1978) as well as expectorant, and antitussive effects (Wang et al, 2007).

\section{Materials and Methods}

Medicinal materials

Solanum nigrum Linne, purchased from Beijing PLA, which was identified by a Professor Sun with voucher No. 2012-5A-52 


\section{Experimental animals and cell lines}

Kunming mice, weighing 18-22 g, half male and half female, were provided by the Laboratory Animal Center of Beijing PLA; tumour lines: liver cancer (H22) was provided by the Affiliated Hospital of Beijing PLA. All experimental procedures were approved by the Animal Research Ethics Committee of PLA.

\section{Reagents and instruments}

ConA: Shanghai Huashun Bioengineering Co., Ltd.; MTT: Sigma, USA; DMSO: Tianjin Damao Chemical Instrument Supply Station; RPMI1640 culture medium: GIBCO, USA; IL-2ELISA kit: Nanjing Jiancheng Reagent Co., Ltd. Other reagents were all of analytical grade: Olympus inverted microscope (OLYMPUS, Japan), low-temperature refrigerated centrifuge (Eppendorf, Germany), clean bench (Suzhou Purification Equipment Co., Ltd.), $\mathrm{CO}_{2}$ incubator (SANYO, Japan), continuous wavelength microplate reader (Bio-RAD).

\section{Experimental Methods}

Preparation of polysaccharides from Solanum nigrum Linne

Referring to the method in Su et al (2011), Solanum nigrum Linne was decocted twice with an 8-fold volume of water with $2 \mathrm{~h}$ each time, and filtered. The filtrates were then combined and dried and Solanum nigrum polysaccharides were obtained.

\section{Effect of polysaccharides from Solanum nigrum Linne on life prolongation rate of tumour-bearing mice}

Kunming mice were randomly divided into 5 groups, with each group containing 10 mice. Under sterile conditions, well-grown ascites were extracted from H22 tumour-bearing mice $7 \mathrm{~d}$ after tumour inoculation, and cell morphology and cell count were observed. When the number of tumour cells exceeded $97 \%$, the ascites were eligible for use and were diluted 1:2 with sterile saline, and inoculated intraperitoneally with $0.3 \mathrm{ml}$ per mouse. $24 \mathrm{~h}$ later, the mice were weighed, and subcutaneously administered with the drug with $0.4 \mathrm{ml}$ per mouse once daily for 7 consecutive days. The doses in Solanum nigrum polysaccharides high-, medium-, and low-dose groups were $120 \mathrm{mg} / \mathrm{kg}, 60 \mathrm{mg} / \mathrm{kg}$ and $30 \mathrm{mg} / \mathrm{kg}$ respectively. Negative control group was given equivalent volume of normal saline, and positive control group was given $100 \mathrm{mg} / \mathrm{kg}$ Astragalus polysaccharides. Life prolongation rate was observed and recorded.

Effect of polysaccharides from Solanum nigrum Linne on lymphocyte proliferation in H22 tumour-bearing mice (Ma et al, 2004; Zhang et al, 2005)

Mice were divided into Solanum nigrum polysaccharides high-, medium-, and low-dose groups, positive control group, negative control group and normal group, with each group containing 10 mice. Under sterile conditions, well-grown ascites were extracted from $\mathrm{H} 22$ tumour-bearing mice $7 \mathrm{~d}$ after tumour inoculation, and cell morphology and cell count were observed. When the number of tumour cells exceeded 97\%, the ascites were eligible for use and were diluted 1:2 with sterile saline, and inoculated intraperitoneally with $0.3 \mathrm{ml}$ per mouse. $24 \mathrm{~h}$ later, the mice were weighed, and the method of administration was the same as in 2.2. On the second day after administration, the mice were sacrificed, spleens were harvested, and spleen tissues were gently crushed in a plate filled with sterile Hank's solution, and sieved with 200 mesh nylon screen to collect spleen cell suspension. Cell concentration was adjusted to $1 \times 10^{6}$ cells $/ \mathrm{mL}$ with RPMI1640 culture medium. The experimental groups included those containing ConA and those without ConA, each well of 96-well plate was added with $100 \mu \mathrm{L}$ of cell suspension plus $100 \mu \mathrm{L}$ of ConA group that did not contain ConA serving as a control. Plates were 
incubated in a $\mathrm{CO}_{2}$ incubator set at $37^{\circ} \mathrm{C}$ for $48 \mathrm{~h} .20 \mu \mathrm{L}$ of MTT solution was added to each well. After incubating for another $4 \mathrm{~h}$, the supernatant was discarded and $150 \mu \mathrm{L}$ of DMSO was added to each well, then the plate was shaken in a micromixer for $10 \mathrm{~min}$. After the crystalline was fully dissolved, absorbance of each well was measured at $570 \mathrm{~nm}$.

\section{Effect of polysaccharides from Solanum nigrum Linne on IL-2 production in H22 tumour-bearing mice}

$100 \mu \mathrm{L}$ of spleen cell suspension were placed in the culture plate, added with $100 \mu \mathrm{L}$ of ConA, and incubated in a $\mathrm{CO}_{2}$ incubator set at $37^{\circ} \mathrm{C}$ for $48 \mathrm{~h}$. Then, the supernatant was collected and cryopreserved at $-20^{\circ} \mathrm{C}$. OD value at $450 \mathrm{~nm}$ was measured with a microplate reader by referring to the mouse IL-2ELISA kit instructions (Shi et al, 2002).

Effect of polysaccharides from Solanum nigrum Linne on intralymphocytic $\mathrm{Ca}^{2+}$ concentration in $\mathrm{H} 22$ tumour-bearing mice

Referring to the method in Zhang et al (2000), after the mice were sacrificed, spleens were harvested under sterile conditions to obtain the spleen cell suspension, and cell concentration was adjusted to $1 \times 10^{9}$ cells/L with RPMI16640 culture medium. $1 \mathrm{~mL}$ of the cell suspension was placed in the eppendorf tube, added with Fluo-3 to make the final concentration 4 $\mu \mathrm{mol} \cdot \mathrm{L}^{-1}$. Then, the suspension was incubated at $37^{\circ} \mathrm{C}$ for $40 \mathrm{~min}$. After washing three times in PBS, the suspension was resuspended in $1 \mathrm{~mL}$. One drop of the suspension was added on the glass slide, allowed to stand for $10 \mathrm{~min}$, and then covered with coverslip. The sample was placed on a laser scanning confocal microscope with 40X eyepiece, with the fluorescence intensity representing the $\mathrm{Ca}^{2+}$, and experimental data were directly input into the computer for processing and image analysis.

\section{Data Processing}

Data were all presented as $\mathrm{x} \pm \mathrm{s}$; one-way ANOVA and comparison among groups were performed using the SPSS 10.0 statistical software.

\section{Results}

Effect of polysaccharides from Solanum nigrum Linne on life prolongation rate of $\mathrm{H} 22$ tumour-bearing mice

The experimental results are shown in Table 1. Each Solanum nigrum polysaccharides dose group can all significantly prolong the survival time of H22 tumour-bearing mice, which were all higher than that of the negative control group, indicating that the Solanum nigrum polysaccharides can extend the survival time of H22 tumour-bearing mice, of which the medium- and high-dose groups had significant survival time prolongation effects. However, the survival times of each dose group were all lower than that of the positive control group.

\section{Effect of polysaccharides from Solanum nigrum Linne on lymphocyte proliferation in $\mathrm{H} 22$ tumour-bearing mice}

The results are shown in Table 2. The number of lymphocytes in tumour-bearing mice was significantly lower than that in the normal group. Different doses of Solanum nigrum polysaccharides all improved the lymphocyte proliferation, of which the medium dose group had better effect. The Solanum nigrum polysaccharides could also enhance the ConA-stimulated lymphocyte proliferation. 


\section{http://dx.doi.org/10.4314/ajtcam.v10i4.7}

Table 1: Effect of polysaccharides from Solanum nigrum Linne on survival time of $\mathrm{H} 22$ tumour-bearing mice $(\mathrm{x} \pm \mathrm{s}, \mathrm{n}=10)$

\begin{tabular}{|c|c|c|c|}
\hline Group & Dose (mg/kg) & Route of administration & Survival time (d) \\
\hline Negative control group & & Ih & $9.87 \pm 2.56$ \\
\hline Positive control group & 100 & Ih & $18.62 \pm 2.31 * *$ \\
\hline Solanum nigrum polysaccharides & 30 & Ih & $12.98 \pm 2.42$ \\
\hline low-dose group & & & \\
\hline $\begin{array}{l}\text { Solanum nigrum polysaccharides } \\
\text { medium-dose group }\end{array}$ & 60 & $\mathrm{Ih}$ & $16.31 \pm 2.01^{* *}$ \\
\hline $\begin{array}{l}\text { Solanum nigrum polysaccharides } \\
\text { high-dose group }\end{array}$ & 120 & Ih & $17.80 \pm 2.78^{* *}$ \\
\hline
\end{tabular}

Note: Comparison with the negative control group: $* * \mathrm{p}<0.01$

Table 2: Effect of polysaccharides from Solanum nigrum Linne on lymphocyte proliferation in tumour-bearing mice $(\mathrm{x} \pm \mathrm{s}$,

\begin{tabular}{|c|c|c|c|c|}
\hline & & & 10) & \\
\hline Group & $\begin{array}{l}\text { Route of } \\
\text { administration }\end{array}$ & Dose $(\mathrm{mg} / \mathrm{kg})$ & Not added with ConA & Added with ConA \\
\hline Normal group & Ih & & $0.5483 \pm 0.1552$ & $0.6732 \pm 0.1783$ \\
\hline Negative control group & Ih & & $0.3422 \pm 0.1124$ & $0.3791 \pm 0.0912$ \\
\hline Positive control group & Ih & 100 & $0.5242 \pm 0.1887 * *$ & $0.6662 \pm 0.1052 * *$ \\
\hline $\begin{array}{l}\text { Solanum nigrum } \\
\text { polysaccharides low-dose } \\
\text { group }\end{array}$ & Ih & 30 & $0.5027 \pm 0.1046^{* *}$ & $0.5827 \pm 0.1083^{* *}$ \\
\hline $\begin{array}{l}\text { Solanum nigrum } \\
\text { polysaccharides } \\
\text { medium-dose group }\end{array}$ & Ih & 60 & $0.5184 \pm 0.2011^{* *}$ & $0.6098 \pm 0.1059^{* *}$ \\
\hline $\begin{array}{l}\text { Solanum nigrum } \\
\text { polysaccharides } \\
\text { high-dose group }\end{array}$ & Ih & 120 & $0.5019 \pm 0.1322 * *$ & $0.5710 \pm 0.1036^{* *}$ \\
\hline
\end{tabular}

Note: Comparison with the negative control group: $* * \mathrm{p}<0.01$

Effect of polysaccharides from Solanum nigrum Linne on IL-2 production in H22 tumour-bearing mice

The results are shown in Table 3. The IL-2 production in tumour-bearing mice was significantly reduced than that in the normal group. After treatment with Solanum nigrum polysaccharides, IL-2 production was significantly improved, of which the effect was better in the medium dose group.

Effect of polysaccharides from Solanum nigrum Linne on intralymphocytic $\mathrm{Ca}^{2+}$ concentration in $\mathrm{H} 22$ tumour-bearing mice

The results are shown in Table 4. Intralymphocytic $\mathrm{Ca}^{2+}$ concentration in tumour-bearing mice was significantly reduced than that in the normal group, while the $\mathrm{Ca}^{2+}$ concentrations in Solanum nigrum polysaccharides groups were significantly increased, and the effect was better in the medium dose group. 
http://dx.doi.org/10.4314/ajtcam.v10i4.7

Table 3: Effect of polysaccharides from Solanum nigrum Linne on IL-2 production in tumour-bearing mice $(\mathrm{x} \pm \mathrm{s}, \mathrm{n}=10)$

\begin{tabular}{|c|c|c|c|}
\hline Group & Route of administration & Dose (mg/kg) & IL-2 \\
\hline Normal group & & & $0.4274 \pm 0.1984$ \\
\hline Negative control group & Ih & & $0.2051 \pm 0.0862$ \\
\hline Positive control group & Ih & 100 & $0.4025 \pm 0.0823 * *$ \\
\hline $\begin{array}{l}\text { Solanum nigrum } \\
\text { polysaccharides low-dose } \\
\text { group }\end{array}$ & Ih & 30 & $0.3234 \pm 0.1045^{*}$ \\
\hline $\begin{array}{l}\text { Solanum nigrum } \\
\text { polysaccharides } \\
\text { medium-dose group }\end{array}$ & Ih & 60 & $0.3921 \pm 0.0842 * *$ \\
\hline $\begin{array}{l}\text { Solanum nigrum } \\
\text { polysaccharides high-dose } \\
\text { group }\end{array}$ & Ih & 120 & $0.3074 \pm 0.0833^{*}$ \\
\hline
\end{tabular}

Note: Comparison with the negative control group: * $\mathrm{p}<0.05,{ }^{* *} \mathrm{p}<0.01$

Table 4: Effect of polysaccharides from Solanum nigrum Linne on intralymphocytic $\mathrm{Ca}^{2+}$ concentration in tumour-bearing

\begin{tabular}{llll} 
& \multicolumn{3}{c}{$\operatorname{mice}(\mathrm{x} \pm \mathrm{s}, \mathrm{n}=10)$} \\
\hline Group & $\begin{array}{l}\text { Route of } \\
\text { administration }\end{array}$ & Dose $(\mathrm{mg} / \mathrm{kg})$ & $2745.52 \pm 1621.68$ \\
\hline $\begin{array}{l}\text { Normal group } \\
\text { Negative control group }\end{array}$ & Ih & & $722.23 \pm 1263.21$ \\
$\begin{array}{l}\text { Positive control group } \\
\text { Solanum nigrum }\end{array}$ & Ih & 100 & $1732.75 \pm 1375.37^{* *}$ \\
$\begin{array}{l}\text { polysaccharides low-dose } \\
\text { group }\end{array}$ & 30 & $1694.47 \pm 1679.58^{* *}$ \\
$\begin{array}{l}\text { Solanum nigrum } \\
\text { polysaccharides }\end{array}$ & ih & & \\
$\begin{array}{l}\text { medium-dose group } \\
\text { Solanum nigrum }\end{array}$ & Ih & 60 & $2949.94 \pm 1906.74 * *$ \\
polysaccharides high-dose & & 120 & $1285.86 \pm 904.43^{*}$ \\
group & & & \\
\hline
\end{tabular}

Note: Comparison with the negative control group: ${ }^{*} \mathrm{p}<0.05, * * \mathrm{p}<0.01$

\section{Discussion}

The above experiments showed that the Solanum nigrum polysaccharides can prolong the survival time of $\mathrm{H} 22$ tumour-bearing mice, promote lymphocyte proliferation, enhance anti-tumour immune function, and thereby achieve the anti-tumour effect. Solanum nigrum polysaccharides can also significantly elevate the level of IL-2, which may be accomplished through promoting lymphocytes to produce lymphokines, thus promoting lymphocyte proliferation and IL-2 production. Chinese medicine polysaccharides mainly improve the host's immune function, and enhance the anti-tumour activity. In the treatment of cancer, immune function enhancement plays an important role in the process of tumour cell elimination (HANSK et al, 2006), while Solanum nigrum polysaccharides have significant survival time prolongation and imunomodulatory effects in tumour-bearing mice, which thus have a good prospect in cancer treatment. 


\section{References}

1. Compilation group of the "Compilation of National Chinese Herbal Medicine." (1978). Compilation of National Chinese Herbal Medicine. Beijing: People's Medical Publishing House.

2. Eldridge (1983). Ccyanogenieeom Poundsidaxseed. Agric. Food Chem. 31(6):1218-1220.

3. HANSK, YEESC, TAESEOKK (2006). Enhancement of antitumour immunity of dendritic cells pulsed with heat-treated tumour lysate in murine pancreatic cancer. Immunology Letters, 103:142-148.

4. Jiangsu New Medical College. (1977). Dictionary of Chinese Materia Medica (1). Shanghai: Shanghai People's Publishing House, 1977: 630.

5. Liu Ying, Zhang Yan-ling, Wang Yan. (2003).The study on process of extracting alkaloid from natural solanum nigrum. Liaoning Tussah Silk. (2): 34-45.

6. Li Xiu-xia, Zhang Hai-yang.(1998). Pharmacological effects and clinical application of Solanum nigrum. Journal of Jiamusi Medical College, 21 (l): 23-25.

7. Ma Ling-di, Wen Shi-hong, Zhang Yan, He Yu-juan, Liu Xiao-shan, Kang Ge-fei, Jiang Ji-kai. (2004). Antitumour efficacy of matrine and its effect on immune function in H22 tumour-bearing mice. Chinese Traditional and Herbal Drugs. 35 (12): 28 .

8. Mi La, Yang Qiu-lin, Nashunmenghe. (2002). Nutrition Ingredients from Solanum nigrum fruit. Journal of Inner Mongolia Agricultural University, 23 (3): 98-100.

9. Shi Lei, Tan Yan, Liu Zhi-qiang, et al. (2002). Effects of immunomodulatory activity of polyssacharide from Ornithogalum Caudatum Ait. Chinese Journal of Immunology, 18 (11): 799-802.

10. Son, Y. O., Kim, J., Lim, JC. (2003). Ripe fruits of Solanum nigrumL. Inhibit cell growth and induces apoptosis inMCF-7 cell. Food and chemical taticology, 5 (1): 1421-1428.

11. Su Yilaqimuge, Su Xiu-lan. (2011). Extracting process optimization of Polysaccharides from Solanum Nigrum L. Journal of Inner Mongolia Medical College, 33 (2):15-19.

12. Wang Li-ye, Wang Nai-li, Yao Xin-sheng. (2007). Non-saponin constituents of Solanum nigrum L. Journal of Chinese Medicinal Materials. 30 (7): 792.

13. YEN G C, HSIEH C L. (2001). Evaluation of cytotoxicty, mutage-nicity and antimutagenicity of emerging edible plant. Food and chemical taticology, 3(3): 1045-1053.

14. Zhang Feng-yun, Lv Xue-ying, Zhang Biao, et al. (2000). Determination of intralymphocytic free calcium concentration by laser confocal imaging system in experimental allergic encephalomyelitis animals. Chinese Journal of Neuroimmunology and Neurology, 7 (3): 171-173.

15. Zhang Xiu-juan, Yu Hui-ru, Geng Dan, Zou Xiang, Ji Chen-feng. (2005). Effect of Auricularia auriculajudae polysaccharide on cell immunity of tumour-bearing mice. Chinese Traditional Patent Medicine, 27 (6):45-47. 